\title{
Tamoya haplonema (Cnidaria: Cubozoa) from Uruguayan and adjacent waters: oceanographic context of new and historical findings
}

\author{
Valentina Leoni ${ }^{1,2,3^{*}+}$, Silvana González ${ }^{1,2,3 \dagger}$, Leonardo Ortega ${ }^{1 \dagger}$, Fabrizio Scarabino ${ }^{1,2,4 \dagger}$, Gabriela Failla Siquier ${ }^{5}$, \\ Alicia Dutra ${ }^{6}$, Luis Rubio ${ }^{1,2}$, Martin Abreu ${ }^{7}$, Wilson Serra ${ }^{1,2,3}$, Ana Gabriella Alonzo Campi ${ }^{6}$, Sergio N. Stampar ${ }^{8+}$ \\ and André C. Morandini ${ }^{9}$
}

\begin{abstract}
New records of the cubozoan jellyfish Tamoya haplonema in Uruguayan waters are reported together with historical records for the region, and associated with the oceanographic conditions at the moment of the finding. Occurrences of the species are mainly associated with positive Sea Surface Temperature Anomalies especially during summer months when the intrusion of warm oceanic waters to the Uruguayan coastline is stronger. This was particularly strong during 2012-2013, when a dry period enhanced this scenario. This species is the only cubozoan present in Uruguay, with a sporadic occurrence and so far has no appreciated negative effects on public health. However, from observed increasing frequency of positive temperature anomalies it would be reasonable to predict a future southward shift in the latitudinal distribution of T. haplonema. In this context, occurrence of this toxic species along Uruguayan coastal waters must be considered with particular attention to the potential negative impact on tourism and on general public health.
\end{abstract}

Keywords: Box jellyfish, Tamoya haplonema, Uruguay, South Atlantic

\section{Introduction}

The cnidarian class Cubozoa comprises approximately 50 described species (Bentlage et al. 2010), mostly restricted to warm waters of the globe (Marques et al. 2003; Morandini et al. 2005). Cubozoans have ecological and medical importance playing an important role in marine food webs, affecting fishing activities and tourism (Kingsford and Mooney 2014). However, knowledge on their ecology and on how oceanographic conditions affect population dynamics and distribution are rare for cubomedusae when compared to scyphomedusae and hydromedusae. This disparity could be explained by a limited knowledge on cubozoan taxonomy, the rarity of

\footnotetext{
* Correspondence: valenleoni64@gmail.com

${ }^{\dagger}$ Equal contributors

'Dirección Nacional de Recursos Acuáticos, Constituyente 1497, C.P 11200

Montevideo, Uruguay

${ }^{2}$ Museo Nacional de Historia Natural, C.C. 399, C.P 11000 Montevideo, Uruguay

Full list of author information is available at the end of the article
}

some taxa, as well as their large temporal and spatial variation in abundance (Kingsford and Mooney 2014).

The box jellyfish Tamoya haplonema Müller, 1859 is one of the two valid species of the genus, also represented by the recently described Tamoya ohboya (Collins et al. 2011). As many other cubozoans, T. haplonema causes severe envenomation (Haddad et al. 2009). Morandini and Marques (1997) reported the first case of envenomation in southeastern Brazilian waters, which produced burning sensation followed by a 7-day period of itching and a permanent scar on the affected skin.

Tamoya haplonema is associated to warm neritic waters of both western and eastern Atlantic Ocean (Mianzan and Cornelius 1999), although records from eastern Atlantic might be considered doubtful (Pagès et al. 1992; Gershwin and Gibbons 2009). In the Southwestern Atlantic, the southernmost record is at $38^{\circ} 39^{\prime} \mathrm{S}, 58^{\circ} 40^{\prime} \mathrm{W}$, off Puerto Quequén, Buenos Aires Province, Argentina (Mianzan and Cornelius 1999; Pastorino 2001). 
In the present study, we aimed to: 1) present new records of Tamoya haplonema in Uruguayan coastal water, 2) review and summarize previous records of this species for Uruguay and adjacent waters, and 3) explore possible association between such records and the oceanographic and climatic context.

\section{Materials and methods}

\section{Study area}

The most relevant oceanographic feature of the Southwestern Atlantic Ocean is the Brazil-Malvinas
Confluence Zone, where the warm poleward-flowing Brazil Current and the cold equatorward-flowing Malvinas/ Falklands Current converge (Fig. 1, Gordon 1981; 1989). The location of this zone shifts seasonally reaching higher latitudes during austral summer (i.e., December 21st to March 21st, Maamaatuaiahutapu et al. 1994; Barré et al. 2006). Shallow coastal waters near the borders of Uruguay and Argentina (i.e., depths $<50 \mathrm{~m}$ ) are highly influenced by the Río de la Plata freshwater discharge that exhibits monthly variations, with higher discharges during the austral fall-winter and the lowest discharge during the

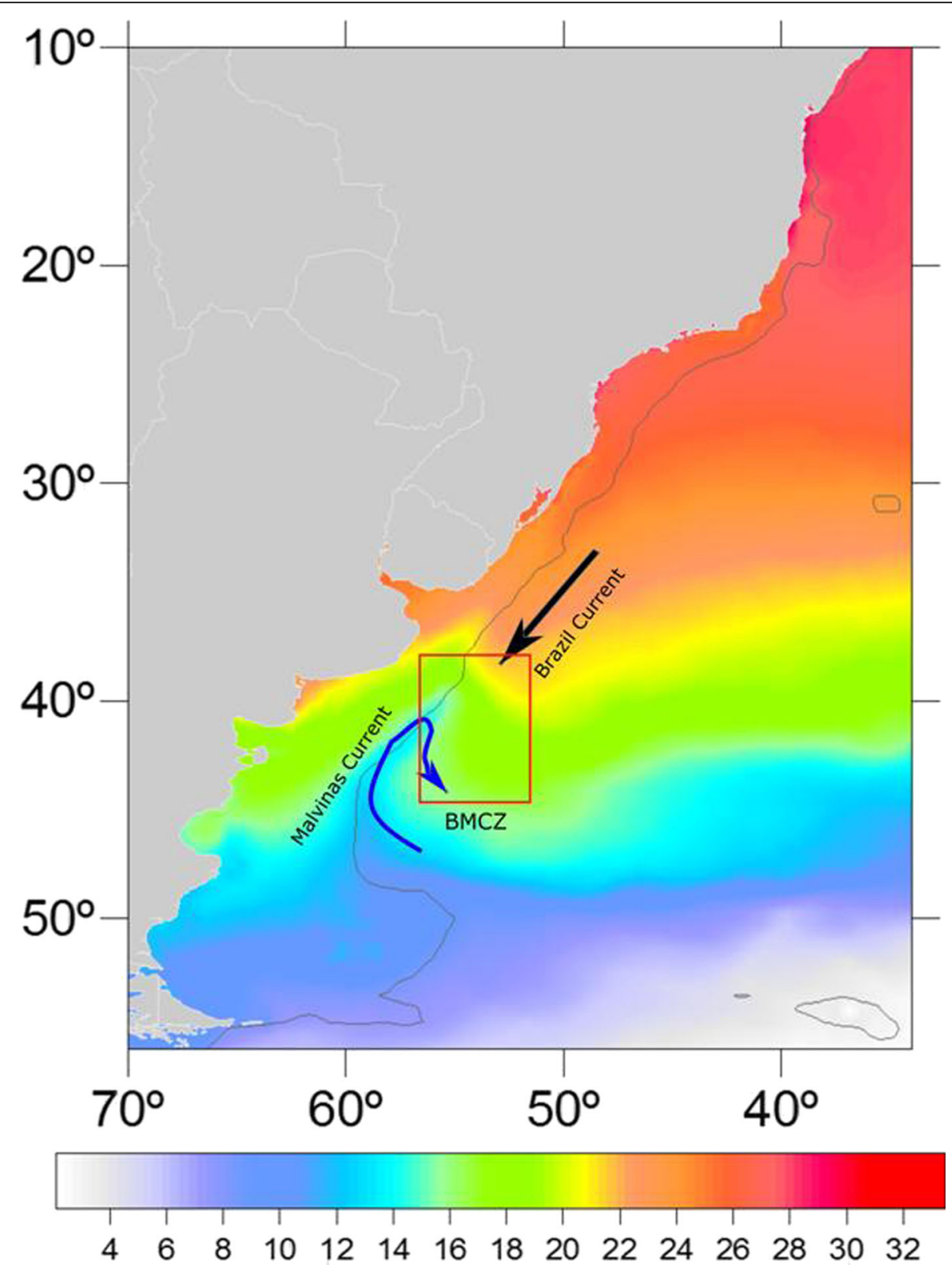

Fig. 1 Schematic representation of the most relevant surface currents of the western South Atlantic. The Brazil-Malvinas/Falklands Confluence Zone (BMCZ) is shown over Aqua MODIS Sea Surface Temperature $\left({ }^{\circ} \mathrm{C}\right)$ austral summer climatology (2002-2013, http://oceancolor.gsfc.nasa.gov/ cgi/l3); the $1000 \mathrm{~m}$ isobath is shown 
austral spring-summer (Sepúlveda et al. 2004). Interannual changes in the precipitation regime mainly connected with El Niño Southern Oscillation (ENSO) (Cazes-Boezio et al. 2003) also influences discharges of Río de la Plata, increasing and decreasing during El Niño and La Niña events, respectively. Thus, the lower freshwater input during austral summer combined with a higher influence of Brazil Current waters in the region, favours the incursion of warm oceanic waters in the coastal area (Ortega and Martínez 2007) which could be enhanced during certain years in response to ENSO cold phase (La Niña).

\section{Literature records, samples identification and measurements}

Published records of cubozoans in the temperate zone of the Southwestern Atlantic Ocean are scarce and were analyzed in detail, even considering particularly cryptic/grey literature as regional conference abstracts. Samples consisted of: a) stranded individuals along the Uruguayan coast (February 1990 and 2007, January and February 2012, and January, February, March and September 2013), and b) specimens collected on board R.V. "Aldebaran" on November 2012. Such specimens were obtained as by-catch of a Engel-type bottom trawl net $(100 \mathrm{~mm}$ stretched mesh in the wings, $50 \mathrm{~mm}$ stretched mesh in the cod ends, $28 \mathrm{~m}$ horizontal aperture and $4 \mathrm{~m}$ vertical opening), used for demersal fish assessment of the Dirección Nacional de Recursos Acuáticos (DINARA). Other records were made by sightings from lifeguards during summer (January 2012, February and March 2013), but specimens were not collected. Since 2011, lifeguards from the Uruguayan coast had been trained by specialists in courses and workshops about identification of gelatinous zooplankton species, receiving guides with photographs and key diagnostic features as well as standardized recording sheets (Failla Siquier and Dutra 2012; Failla Siquier and Dutra 2014).

In order to contextualize the historical presence of $T$. haplonema in the Uruguayan coast we considered: 1) regular efforts made since 1991 during the whole year in recording stranded fauna at Costa Azul - La Aguada in La Paloma (G. Fabiano, pers. comm.; M. Abreu, pers. obs.) and 2) during the last 11 years at La Esmeralda during the summer (A.G. Alonzo Campi, pers. obs.). These included at least two opportunities monthly recording unusual stranding and a weekly periodicity during the summer. These were carried on by professionals that lately found T. haplonema and assured the novelty of that finding since 2012. We also considered 12 trawl coastal surveys (each of ca. 40 tows of 30'each, see other details above) made all over the entire Uruguayan inner shelf since 1999 onboard the R.V. "Aldebaran", personally inspected by two of us (S. González and F. Scarabino).

The specimens were preserved in $5 \%$ formaldehyde solution in sea or freshwater. Identification was made following Morandini et al. (2005) after preservation and measurements were taken in well-preserved specimens. In all collected specimens the umbrella height and width (interpedalia distance, IPD) were measured (maximum, minimum and the average of the four IPD are reported). Pedalia were not preserved properly in some individuals and therefore measurements cannot be provided. The cnidome (set of types and sizes of cnidae from different body parts) was performed from a preserved specimen stranded in La Paloma $\left(34^{\circ} 39^{\prime} \mathrm{S} 54^{\circ} 8^{\prime} \mathrm{W}\right)$ on February 2013 based on methods and nomenclature presented by Collins et al. (2011). Specimens were deposited in the collection of Invertebrate Zoology of the Museo Nacional de Historia Natural (Montevideo, Uruguay) and in the collection of Invertebrate Laboratory of Facultad de Ciencias, Universidad de la República (Montevideo, Uruguay).

\section{Oceanographic and climatic data}

Monthly Sea Surface Temperature Anomalies (SSTA) data were computed from the Extended Reconstructed Sea Surface Temperature, version 3 (ERSST_V3) dataset based on IRI/LDEO Climate Data Library (Xue et al. 2003; Smith et al. 2008). Monthly regional averages of SSTA from 1960 to 2013 were calculated for the area enclosed between latitudes $30^{\circ}$ and $36^{\circ} \mathrm{S}$ and longitudes between $50^{\circ}$ and $60^{\circ} \mathrm{W}$. The analyses were performed using the Ingrid language provided by the IRI Data Library (http://iridl.ldeo.columbia.edu/). Weighted Anomaly Standardized Precipitation information from the IRI Climate Map Room (http://iridl.ldeo.columbia.edu/ maproom/Global/Precipitation/WASP_Indices.html; Lyon 2004; Lyon and Barnston 2005) was used to analyze the relative deficit of precipitation during the 2011-2013 summer period.

During the survey performed in November 2012 on board R.V. "Aldebaran", temperature and salinity data was obtained in situ with CTD (SBE-19 plus, Sea-Bird Electronics).

\section{Results \\ Historical records of $T$. haplonema in Uruguayan and adjacent waters}

The first record of a cubomedusa from Uruguayan coast was made by Barattini and Ureta (1961, sometimes dated as 1960), specifically for the coast of Maldonado, as being uncommon. These authors used (for the first time in cnidarian nomenclature) the name Carybdea atlantica, without providing any nomenclatural information like authority or indication that this was a new name. There was no illustration other than one drawing quoted as "Charibdea marsupialis" apparently given for illustrating the general aspect of a cubomedusa. Moreover, the characters provided in the two paragraphs under C. atlantica are non-informative and shared with several species. Mianzan et al. (1988), Mianzan and Cornelius (1999) 
and Pastorino (2001) commented the mention of Barattini and Ureta (1961) either as dubious and/or possibly conspecific with Tamoya haplonema, considering that this is the only cubomedusa recorded from Uruguayan waters or southward (Goy 1979; Mianzan and Cornelius 1999; Pastorino 2001; Failla Siquier 2006). Pastorino (2001) more specifically referred it as a nomen nudum. It is unclear if Barattini and Ureta (1961) had the intention to describe a new species or if even C. atlantica is a lapsus calami for Carybdea alata Reynaud, 1830 (now Alatina alata, see Gershwin 2005; Lewis et al. 2013). However, we fully support the proposition of Pastorino (2001) to treat Carybdea atlantica Barattini and Ureta, 1961 as a nomen nudum and to refer definitively this record as being based on specimens of Tamoya haplonema. This conclusion is only based on geographical distribution ( $T$. haplonema is the only species recorded from the region) considering that all characters and measurements

Table 1 New and historical records of Tamoya haplonema from Uruguayan and adjacent waters (Argentina and southernmost Brazil). Comparative measurements in $\mathrm{cm}$ (specimens lacking this data were damaged): umbrella and pedalia height, average, maximum and minimum interpedalia distance (IPD)

\begin{tabular}{|c|c|c|c|c|c|c|c|}
\hline Date & Reference & Location & $\begin{array}{l}\text { No. } \\
\text { specimens }\end{array}$ & State & $\begin{array}{l}\text { Umbrella } \\
\text { height }\end{array}$ & IPD & $\begin{array}{l}\text { Pedalia } \\
\text { height }\end{array}$ \\
\hline 28th September 2013 & Present work & $\begin{array}{l}\text { La Aguada, Rocha } \\
\left(34^{\circ} 38^{\prime} \mathrm{S} 54^{\circ} 9^{\prime} \mathrm{W}\right)\end{array}$ & 1 & Stranded & - & - & - \\
\hline 6th March 2013 & Present work & Cabo Polonio Sur, Rocha & 1 & Stranded & - & - & - \\
\hline 4th March 2013 & Present work & Arachania, Rocha & 1 & Stranded/Collected & 6.3 & $4(3.5-4.5)$ & 3.6 \\
\hline 23th February 2013 & Present work & $\begin{array}{l}\text { La Aguada, Rocha } \\
\left(34^{\circ} 38^{\prime} \mathrm{S} 54^{\circ} 9^{\prime} \mathrm{W}\right)\end{array}$ & 1 & Stranded/Collected & 9.4 & $4.0(3.0-5.4)$ & 5.0 \\
\hline 22nd February 2013 & Present work & $\begin{array}{l}\text { Playa Puerto de la Paloma, } \\
\text { Rocha }\left(34^{\circ} 39^{\prime} \mathrm{S} 54^{\circ} 8^{\prime} \mathrm{W}\right)\end{array}$ & 1 & Stranded/Collected & 10.0 & $4.0(3.1-4.4)$ & 5.6 \\
\hline 12nd February 2013 & Present work & Aguas Dulces, Rocha & 1 & Stranded & - & - & - \\
\hline 10th February 2013 & Present work & $\begin{array}{l}\text { Cerro Verde, } \\
\text { Rocha }\end{array}$ & 1 & Stranded/Photographed & - & - & - \\
\hline 16th January 2013 & Present work & $\begin{array}{l}\text { La Esmeralda, Rocha } \\
\left(34^{\circ} 10^{\prime} \mathrm{S} 53^{\circ} 40^{\prime} \mathrm{W}\right)\end{array}$ & 1 & Stranded & - & - & - \\
\hline 28th November 2012 & Present work & $34^{\circ} 13^{\prime} \mathrm{S} 53^{\circ} 30^{\prime} \mathrm{W}$ & 1 & $\begin{array}{l}\text { Collected onboard R.V. } \\
\text { "Aldebaran" }\end{array}$ & 15.8 & $6.3(4.4-8.6)$ & 5.0 \\
\hline 28th November 2012 & Present work & $34^{\circ} 13^{\prime} \mathrm{S} 53^{\circ} 30^{\prime} \mathrm{W}$ & 1 & $\begin{array}{l}\text { Collected onboard R.V. } \\
\text { "Aldebaran" }\end{array}$ & 14.9 & $6.5(5.9-7.1)$ & 5.2 \\
\hline 16th February 2012 & Present work & La Barra, Maldonado & 1 & Stranded/Collected & 14 & $4.4(3.5-5.5)$ & 5.7 \\
\hline 6th February 2012 & Present work & $\begin{array}{l}\text { Port of Punta del Este, } \\
\text { Maldonado }\end{array}$ & 1 & Alive/Photographed & 10 & 6.0 & 5.0 \\
\hline January 2012 & Present work & $\begin{array}{l}\text { La Esmeralda, Rocha } \\
\left(34^{\circ} 10^{\prime} \mathrm{S} 53^{\circ} 40^{\prime} \mathrm{W}\right)\end{array}$ & 2 & Stranded/1 collected & 8.4 & $4.5(4.1-5.0)$ & 4.0 \\
\hline 30th January 2012 & Present work & La Paloma, Rocha & 1 & Stranded & - & - & - \\
\hline 23rd February 2007 & Present work & La Paloma, Rocha & 1 & Stranded/Collected & 8.75 & $4.7(4.2-5.0)$ & 4.8 \\
\hline December 2004 & Failla-Siquier 2006 & Valizas, Rocha & 1 & Stranded/Collected & 6.5 & $3.7(3.0-4.5)$ & 4.0 \\
\hline 26th May 2000 & Pastorino 2001 & $\begin{array}{l}\text { Off Puerto Quequén, } \\
\text { Argentina }\left(38^{\circ} 39^{\prime} \mathrm{S} 58^{\circ} 40^{\prime} \mathrm{W}\right)\end{array}$ & 1 & Collected onboard & 9.0 & 7.2 & 3.0 \\
\hline 26th May 2000 & Pastorino 2001 & $\begin{array}{l}\text { Off Puerto Quequén, } \\
\text { Argentina }\left(38^{\circ} 39^{\prime} \mathrm{S} 58^{\circ} 40^{\prime} \mathrm{W}\right)\end{array}$ & 1 & Collected onboard & 8.3 & 6.6 & 2.7 \\
\hline January 1993 & Failla-Siquier 2006 & Rocha & 1 & Stranded & - & - & - \\
\hline 20th February 1990 & Present work & $\begin{array}{l}\text { La Paloma (Bahía Chica), } \\
\text { Rocha }\end{array}$ & 1 & Stranded/Collected & 6 & 4.5 & - \\
\hline 8th January 1962 & Goy 1979 & $\begin{array}{l}\text { Southernmost Brazil } \\
\left(33^{\circ} 48^{\prime} \mathrm{S} 53^{\circ} 08^{\prime} \mathrm{W}\right)\end{array}$ & 1 & $\begin{array}{l}\text { Collected onboard R.V. } \\
\text { "Calypso" }\end{array}$ & 11.0 & 8.5 & - \\
\hline 21st December 1961 & Goy 1979 & $\begin{array}{l}\text { Off Punta del Diablo, } \\
\left.\text { Rocha ( } 34^{\circ} 07^{\prime} \mathrm{S} 53^{\circ} 12^{\prime} \mathrm{W}\right)\end{array}$ & 2 & $\begin{array}{l}\text { Collected onboard R.V. } \\
\text { "Calypso" }\end{array}$ & 11.0 & 8.5 & - \\
\hline- & $\begin{array}{l}\text { Barattini and } \\
\text { Ureta } 1961\end{array}$ & Maldonado & - & - & - & - & - \\
\hline
\end{tabular}


given by Barattini and Ureta (1961) are vague. It must be pointed out that the closest geographical record of Alatina alata (as Carybdea alata) is from deep trawls (1067 m depth) off Bahia state (Brazil) at $14^{\circ} \mathrm{S} 38^{\circ} \mathrm{W}$ approximately $3,000 \mathrm{~km}$ away from Uruguay (Morandini 2003).

Reliable records of $T$. haplonema for the Uruguayan coast are indeed scarce and consists of only two specimens recorded by Goy (1979) and collected off Punta

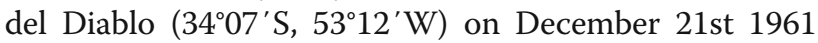
during the cruise of the R.V. Calypso at a depth of 20$22 \mathrm{~m}$ and a surface temperature of $20.8^{\circ} \mathrm{C}$ (Forest 1966). Another record of this species from southernmost Brazilian waters, very close to Uruguay, also comes from the R.V. Calypso collected on January 8th $1962\left(33^{\circ} 48^{\prime}\right.$ S, $53^{\circ} 08^{\prime} \mathrm{W}, 19 \mathrm{~m}$ ) (Goy 1979). Failla Siquier (2006) recorded cubomedusae specimens found stranded in the coast of Rocha, Uruguay on January 1993 and December 2004 identifying them with doubts (due to the poor condition of the material) as T. haplonema. Following the same rationale applied to the record of Barattini and Ureta (1961), we consider these records as T. haplonema.

\section{New records of Tamoya haplonema from Uruguayan coast (Southwestern Atlantic Ocean)}

The following diagnostic characters were observed in well preserved specimens: 1 ) bell elongate cuboid, longer than wide, and translucid, 2) four lateral perradial rhopaliar with horizontal rhopaliar niche opening, 3) four simple inter-radial pedalia and one tentacle by pedalium and 4) four vertically arranged phacellae. The extreme values of two measures for all specimens collected are $6-$ $15.8 \mathrm{~cm}$ (for umbrella height) and $3.6-5.7 \mathrm{~cm}$ (for pedalium height) (Table 1). Characterization of cnidome of different body parts of a specimen stranded in La Paloma was made, measuring capsule lengths and widths (Table 2). Nowadays, the absence of small oval amastigophore nematocysts in the tentacle base of T. haplonema is a feature that distinguishes the species.

The new records of $T$. haplonema consist of 17 specimens including: a) 14 stranded individuals in Rocha and Maldonado, b) two specimens collected on board R.V.

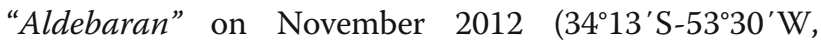
22 m, i.e., off Punta del Diablo, Rocha), and c) one sighting on board on February 2012 in Maldonado (Figs. 2 and 3, Table 1). Three records of the stranded specimens were made by lifeguards in Rocha during summer months (January to March) but those were not collected neither photographed.

\section{Oceanographic and climatic context of regional water records}

The long term analysis of regional mean SSTA, showed an increasing trend from 1960 to 2013 in the study area (Fig. 4), with a predominance of positive anomalies
Table 2 Cnidome of different body parts of a Tamoya haplonema specimen from Uruguay

\begin{tabular}{|c|c|c|c|c|}
\hline \multicolumn{5}{|c|}{ Tamoya haplonema (La Paloma, Uruguay) } \\
\hline Tentacle tip & Mean (range) L & Mean (range) W & N & Abundance \\
\hline $\begin{array}{l}\text { Macrobasic } \\
\text { p-eurytele }\end{array}$ & $41.6(35.5-49.6)$ & $16.1(14.1-19.2)$ & 30 & Abundant \\
\hline $\begin{array}{l}\text { Microbasic } \\
\text { birhopaloid }\end{array}$ & $23.1(21.2-26.7)$ & $14.1(12.1-16.2)$ & 30 & Rare \\
\hline $\begin{array}{l}\text { Holotrichous } \\
\text { isorhiza }\end{array}$ & $28.2(24.6-31.2)$ & $22.4(18.1-24.8)$ & 30 & Fair \\
\hline \multicolumn{5}{|l|}{ Tentacle Base } \\
\hline $\begin{array}{l}\text { Macrobasic } \\
\text { p-eurytele }\end{array}$ & $51.2(46.2-53.4)$ & $16.5(14.4-18.2)$ & 30 & Abundant \\
\hline Oval isorhiza & $14.6(9.2-16.6)$ & $9.5(8.1-12.2)$ & 20 & Rare \\
\hline $\begin{array}{l}\text { Holotrichous } \\
\text { isorhiza }\end{array}$ & $29.6(25.2-33)$ & $23.6(20-25.8)$ & 30 & Fair \\
\hline $\begin{array}{l}\text { Microbasic } \\
\text { p-birhopaloid }\end{array}$ & $25.5(22.2-27.3)$ & $18.2(14.5-20.5)$ & 30 & Fair \\
\hline $\begin{array}{l}\text { Holotrichous } \\
\text { isorhiza }\end{array}$ & $27.5(25.2-30)$ & $22(18.5-23.1)$ & 30 & Fair \\
\hline \multicolumn{5}{|l|}{ Phacellae } \\
\hline $\begin{array}{l}\text { Microbasic } \\
\text { p-birhopaloid }\end{array}$ & $21.2(19.5-22.9)$ & $15.8(12.8-18.9)$ & 30 & Fair \\
\hline $\begin{array}{l}\text { Holotrichous } \\
\text { isorhiza }\end{array}$ & $32.5(28.5-34.8)$ & $26.5(23.1-29.4)$ & 10 & Rare \\
\hline \multicolumn{5}{|l|}{ Pedalial Warts } \\
\hline $\begin{array}{l}\text { Holotrichous } \\
\text { isorhiza }\end{array}$ & $34.5(27.5-36.6)$ & $29.8(25.5-31.6)$ & 30 & Fair \\
\hline Oval isorhiza & $11.2(8.6-12.9)$ & $7.8(6.5-8.9)$ & 10 & Rare \\
\hline \multicolumn{5}{|l|}{ Bell Warts } \\
\hline $\begin{array}{l}\text { Holotrichous } \\
\text { isorhiza }\end{array}$ & $33.6(29.5-36.4)$ & $28.2(26.7-30.1)$ & 30 & Fair \\
\hline Oval isorhiza & $10.5(9.6-13.2)$ & $8.7(7-10.2)$ & 10 & Rare \\
\hline \multicolumn{5}{|l|}{ Apex Warts } \\
\hline $\begin{array}{l}\text { Holotrichous } \\
\text { isorhiza }\end{array}$ & $31.2(28.4-36.5)$ & $28.6(26.9-32.2)$ & 20 & Rare \\
\hline Oval isorhiza & $11.1(8.9-12.8)$ & $8.5(6.8-10.4)$ & 10 & Rare \\
\hline
\end{tabular}

$\mathrm{L}$ and $\mathrm{W}$ denote capsule lengths and widths, respectively, in $\mu \mathrm{m} . N$ means number of undischarged capsules measured

mainly after 2000. Most of the records match with the occurrence of positive SSTA (ca. $80 \%$ ) in the region during the month of the finding (Fig. 4) or during spring in a period characterized by a strong La Niña event. Moreover, nearly $80 \%$ of the records of T. haplonema correspond to austral summer when the influence of warm oceanic waters from the Brazil Current is higher in the area.

The specimens collected on board R.V. "Aldebaran" in November 2012 in the coastal area of Rocha were associated with relatively warm and salty waters (mean water column temperature $=18.16(\mathrm{SD} \pm 1.32)$ and salinity 30.64 ( $\mathrm{SD} \pm 0.28)$ ) whereas surface temperature and salinity were $19.10{ }^{\circ} \mathrm{C}$ and 30.62 respectively, suggesting the 


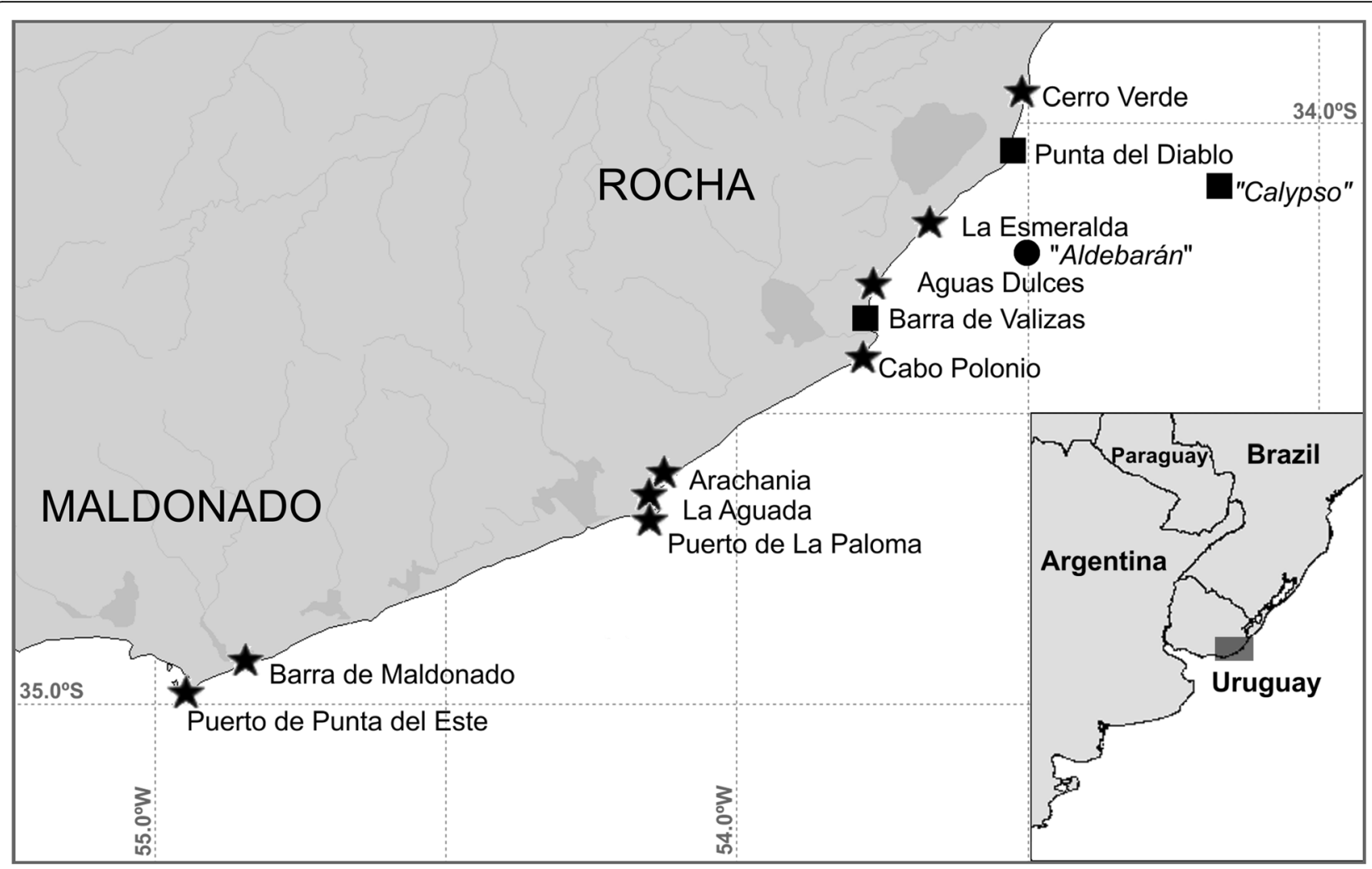

Fig. 2 Locations of new (stars and point) and historical records (square) of Tamoya haplonema from Uruguayan waters

early influence of warm oceanic waters in the coastal area (November surface temperature climatology from 19602013 period $=18.75{ }^{\circ} \mathrm{C}$ ). This finding belongs to a period of several records along 2012-2013, which includes the majority of the findings so far recorded from the area.

\section{Discussion}

All new records belong to the coast/inner shelf, i.e., matching the habitat already reported for Tamoya haplonema (Mianzan and Cornelius 1999). Morphological measurements also fall within those values previously stated for this species (see Mianzan and Cornelius 1999; Morandini et al. 2005). The cnidome data here presented (Table 2) for a single specimen of $T$. haplonema in comparison with the one shown by Collins et al. (2011, Table 1) for Tamoya ohboya demonstrate that in some cases there is superposition of values.

Despite an increasing effort of jellyfish monitoring on the Uruguayan coast in the last years, and also because cubozoans are easy to detect between other invertebrates, $T$. haplonema can be currently considered occasional in this region with a good basis. This is reinforced

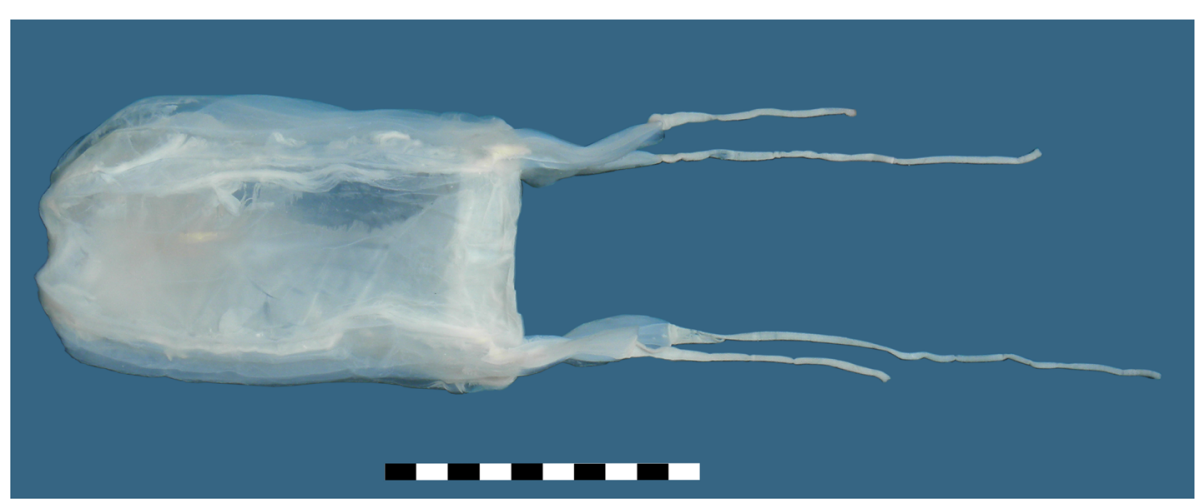

Fig. 3 Specimen of Tamoya haplonema collected on board R.V. "Aldebaran" on November 2012. Scale: $10 \mathrm{~cm}$ 


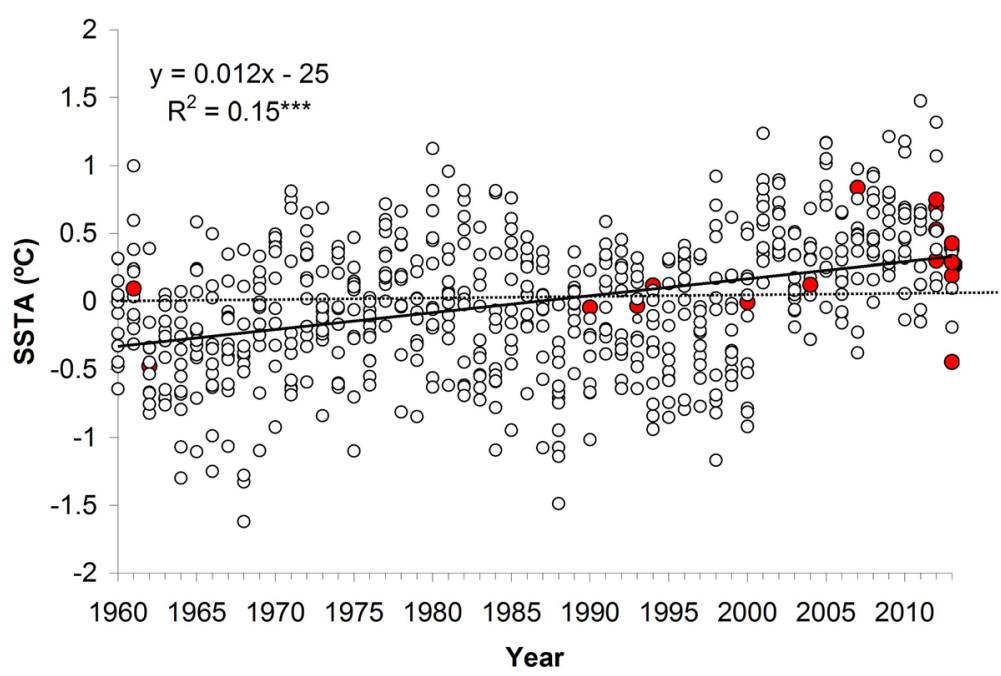

Fig. 4 Long term variation in monthly Sea Surface Temperature Anomaly $\left({ }^{\circ} \mathrm{C}\right.$, SSTA) for the region comprised between latitudes $30^{\circ}$ and $36^{\circ} \mathrm{S}$ and longitudes between $50^{\circ}$ and $60^{\circ} \mathrm{W}$. Filled dots correspond to SSTA values for the months with records of Tamoya haplonema in Uruguayan and adjacent waters. ${ }^{* * *} \mathrm{p}<0.001$

by the absence of records of this species during 2014 and 2015 on the Uruguayan coast despite the increasing record of stranded jellyfishes since 2011. Thus, the presence of $T$. haplonema could be associated with the occurrence of positive SSTA in the region (ca. $80 \%$ of records) especially during summer months, when intrusion of warm oceanic waters to the Uruguayan coastline is stronger. The occurrence was particularly and unusually strong during 2012-2013. Spring of 2011 and summer of 2012 were under the influence of a cold ENSO episode (La Niña) that is characterized by negative sea surface temperature anomalies (SSTA) in the Niño 3.4 region $\left(5^{\circ} \mathrm{N}-5^{\circ} \mathrm{S}\right.$, $\left.120^{\circ}-170^{\circ} \mathrm{W}\right)$. These conditions continued over summer 2013 but not surpassing the threshold needed to declare a cold ENSO episode. The aforementioned period was categorized as a dry one for the La Plata basin (http://iridl.ldeo.columbia.edu/maproom/Global/Precipitation). This could have determined an enhanced marine influence during 2012-2013 and the concomitant advection of tropical fauna.

The historical sporadic presence of T. haplonema in the Uruguayan coast and its common presence during 20122013 are supported by the observations made since 1991 during the whole year in recording stranded fauna at La Paloma and during the last 11 years on summer at La Esmeralda. This was also confirmed by our colleague M. Demicheli (pers. comm.), who made similar observations at La Paloma between 1965 and 2002 and found T. haplonema only twice. Moreover, the specimens obtained in November 2012 constitutes the firsts records of $T$. haplonema in at least 12 coastal trawl surveys of similar characteristics made all over the entire Uruguayan inner shelf since 1999 (S. González and F. Scarabino, pers. obs.).

The occurrence of T. haplonema in May 2000 in the coast off Buenos Aires (i.e., southernmost record of the species) was within a period characterized by a strong La Niña event (http://www.cpc.ncep.noaa.gov/products/ analysis_monitoring/ensostuff/ensoyears.shtml). This also coincided with the occurrence of other unusual subtropical species as the brachyuran crab Arenaeus cribrarius and the cephalopod Argonauta nodosa (Scelzo 2001; Pastorino and Tamini 2002), reported for the same period and region. The presence of this subtropical fauna at higher latitudes could be ascribed to the particular atmospheric and oceanographic conditions of that year. The combined effects of onshore winds and a strong La Niña event, implying a decreased freshwater runoff (Cazes Boezio et al., 2003), could enhance the influence of warm oceanic waters from the north (Ortega and Martínez 2007).

The observed increasing trend in SSTA is in agreement with the observations of Zavialov et al. (1999) who reported a positive secular trend of Sea Surface Temperature (SST) for this region (significantly above the global average of SST increase) with most of this warming occurring after 1940. Ortega et al. (2013) also reported a regime shift from a cold to a warm period after 1998 for the study area with a regional predominance of positive SSTA thereafter. This increasing trend in SST and predominance of positive SSTA could be associated with decadal cycles in climate that favour the intrusion of warm oceanic waters in the area which is supported by the occurrence in recent years of other species commonly associated to tropical or subtropical waters as the fishes Stellifer rastrifer (Segura et al. 2009) and Aluterus scriptus (Izzo et al. 2010). Moreover, Ortega et al. (2013) reported for this area an increase in the frequency and speed of onshore winds that could enhance the advection of warm oceanic waters and its associated biota to the coast during austral summer. In this context of increasing frequency of positive SSTA, it 
would be reasonable to predict a future more permanent range extension of $T$. haplonema as sea water temperature increases, considering that the distributional range of cubozoan species is greatest in tropical waters with few species found beyond the tropics, north and south (Orellana and Collins 2011; Kingsford and Mooney 2014). That climate-related expansion to higher latitudes has been mentioned as a possible cause of the occurrence of other species of cubozoans as Copula sivickisi in Japanese waters (Morandini et al. 2014) and Tripedalia cystophora in Australian waters (Ekins and Gershwin 2014).

Currently, T. haplonema is the only cubomedusa present in Uruguay, with a sporadic occurrence and so far has no detected negative effects. However, the presence of this species in Uruguayan waters must be considered with particular attention due to the potential impact on tourism and general public health. This is especially important considering that its occurrence in the coast is associated to a stronger influence of warm subtropical waters during austral summer, i.e. when the influx of tourist to the beach is higher. This also applies to other jellyfishes in Uruguay (considering also its economic and ecological interest) and indicates the need of supporting research and outreach programs focusing on gelatinous zooplankton, mainly to get baseline data on the abundance of different species in the country.

\section{Acknowledgments}

We dedicate this work to the memory of our colleague and friend Hermes W. Mianzan (1957-2014) who took the first step in the study of jellyfish in Uruguay. We are especially grateful to Graciela Fabiano (DINARA) for the samples, data and discussions shared as well as to the entire crew of the R.V. "Aldebaran" for their help during the fieldwork, particularly to E. Chiesa for his permanent support. We are also grateful to lifeguards for their contribution in the monitoring of this group on the beach, and to $\mathrm{M}$. Demicheli for sharing his experience about the presence of $T$. haplonema in La Paloma. R. Capitoli (†) generously donated literature relevant to this note. We want to thank to the two anonymous reviewers for their valuable suggestions. ACM was supported by grants 2010/50174-7 and 2011/50242-5 São Paulo Research Foundation (FAPESP), and by CNPq (301039/2013-5). SNS was supported by grant CNPq (481549/2012-9). This is a contribution of NP-BioMar, USP.

\section{Authors' contributions}

All authors read and approved the final manuscript.

\section{Competing interests}

The authors declare that they have no competing interests.

\section{Author details}

'Dirección Nacional de Recursos Acuáticos, Constituyente 1497, C.P 11200 Montevideo, Uruguay. ${ }^{2}$ Museo Nacional de Historia Natural, C.C. 399, C.P 11000 Montevideo, Uruguay. InvBiota. Invertebrados del Uruquay, Montevideo, Uruguay. ${ }^{4}$ Centro Universitario Regional Este, Sede Rocha, Universidad de la República, Ruta 9, Km 208, C.P 27000 Rocha, Uruguay. ${ }^{5}$ Lab. Zoología de Invertebrados, Dpto. de Biología Animal, Facultad de Ciencias, Universidad de la República, CP 11400 Montevideo, Uruguay. ${ }^{6}$ Prof. de Ciencias Biológicas egresada del I.P.A, Montevideo, Uruguay. ${ }^{7}$ COENDU, Conservación de Especies Nativas del Uruguay, Montevideo, Uruguay. ${ }^{8}$ Departamento de Ciências Biológicas, Faculdade de Ciências e Letras, Unesp - Univ Estadual Paulista, Assis, Av. Dom Antonio, 2100, Assis 19806-900, Brazil. ${ }^{9}$ Departamento de Zoologia.
Instituto de Biociências, Universidade de São Paulo, Rua do Matão, Trav. 14, n. 101, São Paulo, SP 05508-090, Brazil.

Received: 27 July 2016 Accepted: 27 July 2016

Published online: 11 October 2016

\section{References}

Barattini LP, Ureta EH. ("1960") La fauna de las costas del este (invertebrados). Montevideo: Publicaciones de Divulgación Científica, Museo «Dámaso Antonio Larrañaga»; 1961. p. 195.

Barré N, Provost C, Saraceno M. Spatial and temporal scales of the Brazil-Malvinas Current confluence documented by simultaneous MODIS Aqua $1.1-\mathrm{km}$ resolution SST and color images. Nat Hazards Oceanographic Proc Satellite Data. 2006;37:770-86.

Bentlage B, Cartwright P, Yanagihara AA, Lewis C, Richards GS, Collins AG. Evolution of box jellyfish (Cnidaria: Cubozoa), a group of highly toxic invertebrates. Pro R Soc Biol Sci. 2010;1707:1-10.

Cazes-Boezio G, Robertson AW, Mechoso CR. Seasonal dependence of ENSO teleconnections over South America and relationships with precipitation in Uruguay. J Clim. 2003;16:1159-76.

Collins AG, Bentlage B, Gillan W, Lynn TH, Morandini AC, Marques AC. Naming the Bonaire banded box jelly, Tamoya ohboya, n.sp. (Cnidaria: Cubozoa: Carybdeida: Tamoyidae). Zootaxa. 2011;2753:53-68.

Ekins M, Gershwin L. First record of the Caribbean box jellyfish Tripedalia cystophora in Australian waters. Mar Biodivers Rec. 2014;7:e127.

Failla Siquier MG. Zooplancton gelatinoso de la costa uruguaya. In: Menafra R, Rodríguez-Gallego L, Scarabino F, Conde D, editors. Bases para la Conservación y el Manejo de la Costa Uruguaya. Montevideo: Vida Silvestre Uruguay; 2006. p. 97-103.

Failla Siquier MG, Dutra AA. Experiencia preliminar de relevamiento de organismos gelatinosos (Cnidaria y Ctenophora) con la colaboración de los Guardavidas de las playas de los Dptos. de Maldonado y Rocha. Montevideo: Uruguay. Segundo Congreso Uruguayo de Zoologia. Facultad de Ciencias; 2012. p. 163.

Failla Siquier G, Dutra Alburquerque A. Avances del relevamiento de organismos gelatinosos costeros en Uruguay. Montevideo: Tercer Congreso Uruguayo de Zoología. Facultad de Ciencias; 2014. p. 193.

Forest J. Campagne de la Calypso au large des côtes de l'Amérique du Sud (1961-1962) (Première partie). 1. Compte rendu et liste des stations. Ann Inst Oceanogr. 1966;44:329-50.

Gershwin L. Carybdea alata auct. and Manokia stiasnyi, reclassification to a new family with description of a new genus and two new species. Mem Qld Mus. 2005;51:501-23.

Gershwin L, Gibbons MJ. Carybdea branchi, sp. nov., a new box jellyfish (Cnidaria: Cubozoa) from South Africa. Zootaxa. 2009;2088:41-50.

Gordon AL. South Atlantic thermocline ventilation. Deep-Sea Res. 1981;28:1239-64.

Gordon AL. Brazil-Malvinas Confluence. 1984. Deep-Sea Res. 1989;36:359-84.

Goy J. Campagne de la Calypso au large des côtes atlantiques de l'Amérique du sud (1961-1962). 35, vol. 55. Meduses: Résultats Scientifiques des Campagnes de la Calypso 11. Annales de l'Institut Oceanographique; 1979. p. 263-96.

Haddad V, Lupi O, Lonza JP, Tyring SK. Tropical dermatology: Marine and aquatic dermatology. J Am Acad Dermatol. 2009;61:733-59.

Izzo P, Milessi AC, Ortega L, Segura AM. First record of Aluterus scriptus (Monacanthidae) in Mar del Plata, Argentina. Mar Biodivers Rec. 2010;3:1-2.

Kingsford MJ, Mooney CJ. The ecology of box jellyfishes (Cubozoa). In: Pitt KA, Lucas CH, editors. Jellyfish Blooms. Dordrecht: Springer; 2014. p. 267-302.

Lewis C, Bentlage B, Yanagihara AA, Gillan W, van Blerk J, Keil DP, Belly AE, Collins AG. Redescription of Alatina alata (Reynaud, 1830) (Cnidaria: Cubozoa) from Bonaire, Dutch Caribbean. Zootaxa. 2013;3737:473-87.

Lyon B. The strength of El Niño and the spatial extent of tropical drought. Geophysical Res Lett. 2004;31:L21204.

Lyon B, Barnston AG. ENSO and the spatial extent of interannual precipitation extremes in tropical land areas. J Clim. 2005;18:5095-109.

Maamaatuaiahutapu K, Garçon VC, Provost C, Boulahdid M, Bianchi AA. Spring and winter water mass composition in the Brazil-Malvinas Confluence. J Mar Res. 1994;52:397-426.

Marques AC, Morandini AC, Migotto AE. Synopsis of knowledge on Cnidaria Medusozoa from Brazil. Biota Neotrop. 2003;3:1-18. 
Mianzan HM, Cornelius PFS. Scyphomedusae and Cubomedusae of the south Atlantic. In: Boltovskoy D, editor. South Atlantic Zooplankton, vol. 1. Leiden: SPB Academic Publishing; 1999. p. 513-59.

Mianzan HM, Olague G, Montero R. Scyphomedusae de las aguas uruguayas. Spheniscus. 1988;6:1-9.

Morandini AC. Deep-sea medusae (Cnidaria: Cubozoa, Hydrozoa and Scyphozoa) from the coast of Bahia (western South Atlantic, Brazil). Mitteilungen aus dem Hamburgischen Zoologischen Museum und Institut. 2003;100:13-25.

Morandini AC, Marques AC. "Morbakka" syndrome: first report of envenomation by cubozoa (cnidaria) in Brazil. In: VII Congreso Latino-Americano sobre Ciencias do Mar, Resumos Expandidos, vol. 2. Santos: Inst. Oceanogr. USP; 1997. p. 188-9.

Morandini AC, Ascher D, Stampar SN, Ferreira JFV. Cubozoa e Scyphozoa (Cnidaria: Medusozoa) de águas costeiras do Brasil. Iheringia, Série Zoologia. 2005:95:281-94.

Morandini AC, Stampar SN, Kubota S. Mass occurrence of the cubomedusa Copula sivickisi (Cnidaria: Cubozoa) at Seto Harbor, Shirahama, Wakayama, Japan in summer 2013; a possible recent example of global warming. Publ Seto Mar Biol Lab. 2014;42:108-11.

Orellana ER, Collins AG. First report of the box jellyfish Tripedalia cystophora (Cubozoa: Tripedaliidae) in the continental USA, from Lake Wyman, Boca Raton, Florida. Mar Biodivers Rec. 2011:4:1-3.

Ortega L, Martínez A. Multiannual and seasonal variability of water masses and fronts over the Uruguayan shelf. J Coastal Res. 2007;23:629-81.

Ortega L, Celentano E, Finkl C, Defeo O. Effects of climate variability on the morphodynamics of Uruguayan sandy beaches. J Coastal Res. 2013;29:747-55

Pagès F, Gili JM, Bouillon J. Medusae (Hydrozoa, Scyphozoa, Cubozoa) of the Benguela Current (southeastern Atlantic). Sci Mar. 1992;56:1-64.

Pastorino G. New record of the cubomedusae Tamoya haplonema Müller, 1859 (Cnidaria: Scyphozoa) in the South Atlantic. Bull Mar Sci. 2001;68:357-60.

Pastorino G, Tamini L. Argonauta nodosa Solander, 1786 (Cephalopoda: Argonautidae) in Argentine waters. J Conchology. 2002;37(5):477-82.

Scelzo MA. First record of the portunid crab Arenaeus cribrarius (Lamarck, 1818) (Crustacea: Brachyura: Portunidae) in marine waters of Argentina. Proc Biol Soc Wash. 2001;114:605-10

Segura AM, Carranza A, Rubio LE, Ortega L, García M. Stellifer rastrifer (Pisces: Sciaenidae): first Uruguayan records and a $1200 \mathrm{~km}$ range extension. Mar Biodivers Rec. 2009;2:e67. doi:10.1017/S1755267209000852.

Sepúlveda H, Valle-Levinson A, Framinan M. Observations of subtidal and tidal flow in the Rio de la Plata Estuary. Cont Shelf Res. 2004;24:509-25.

Smith TM, Reynolds RW, Peterson TC, Lawrimore J. Improvements to NOAA's Historical Merged Land-Ocean Surface Temperature Analysis (1880-2006). J Clim. 2008;21:2283-96.

Xue Y, Smith TM, Reynolds RW. Interdecadal changes of 30-yr SST normals during 1871-2000. J Clim. 2003:16:1601-12.

Zavialov P, Wainer I, Absy JM. Sea surface temperature variability off southern Brazil and Uruguay as revealed from historical data since 1854. J Geophys Res. 1999;104:21021-32.

\section{Submit your next manuscript to BioMed Central and we will help you at every step:}

- We accept pre-submission inquiries

- Our selector tool helps you to find the most relevant journal

- We provide round the clock customer support

- Convenient online submission

- Thorough peer review

- Inclusion in PubMed and all major indexing services

- Maximum visibility for your research

Submit your manuscript at www.biomedcentral.com/submit

) Biomed Central 